\title{
WASTE INCIDENTAL TO REPROCESSING EVALUATION FOR DISPOSING SALTCAKE TO SALTSTONE
}

February 2002

Westinghouse Savannah River Company

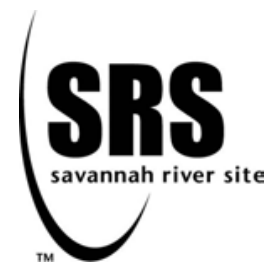

High Level Waste Division

Aiken, SC 29808

Prepared for U.S. Department of Energy Under Contract No. DE-AC09-96SR18500 
This document was prepared in conjunction with work accomplished under Contract No. DE-AC09-96SR18500 with the U. S. Department of Energy.

\section{DISCLAIMER}

This report was prepared as an account of work sponsored by an agency of the United States Government. Neither the United States Government nor any agency thereof, nor any of their employees, makes any warranty, express or implied, or assumes any legal liability or responsibility for the accuracy, completeness, or usefulness of any information, apparatus, product or process disclosed, or represents that its use would not infringe privately owned rights. Reference herein to any specific commercial product, process or service by trade name, trademark, manufacturer, or otherwise does not necessarily constitute or imply its endorsement, recommendation, or favoring by the United States Government or any agency thereof. The views and opinions of authors expressed herein do not necessarily state or reflect those of the United States Government or any agency thereof.

This report has been reproduced directly from the best available copy.

Available for sale to the public, in paper, from: U.S. Department of Commerce, National Technical Information Service, 5285 Port Royal Road, Springfield, VA 22161, phone: (800) 553-6847, fax: (703) 605-6900

email: orders@ntis.fedworld.gov

online ordering: http://www.ntis.gov/help/index.asp

Available electronically at http://www.osti.gov/bridge

Available for a processing fee to U.S. Department of Energy and its contractors, in paper, from: U.S. Department of Energy, Office of Scientific and Technical Information, P.O. Box 62, Oak Ridge, TN 37831-0062,

phone: (865)576-8401,

fax: (865)576-5728

email: $\underline{\text { reports@ adonis.osti.gov }}$ 
Waste Incidental to Reprocessing Evaluation for Disposing Saltcake to Saltstone

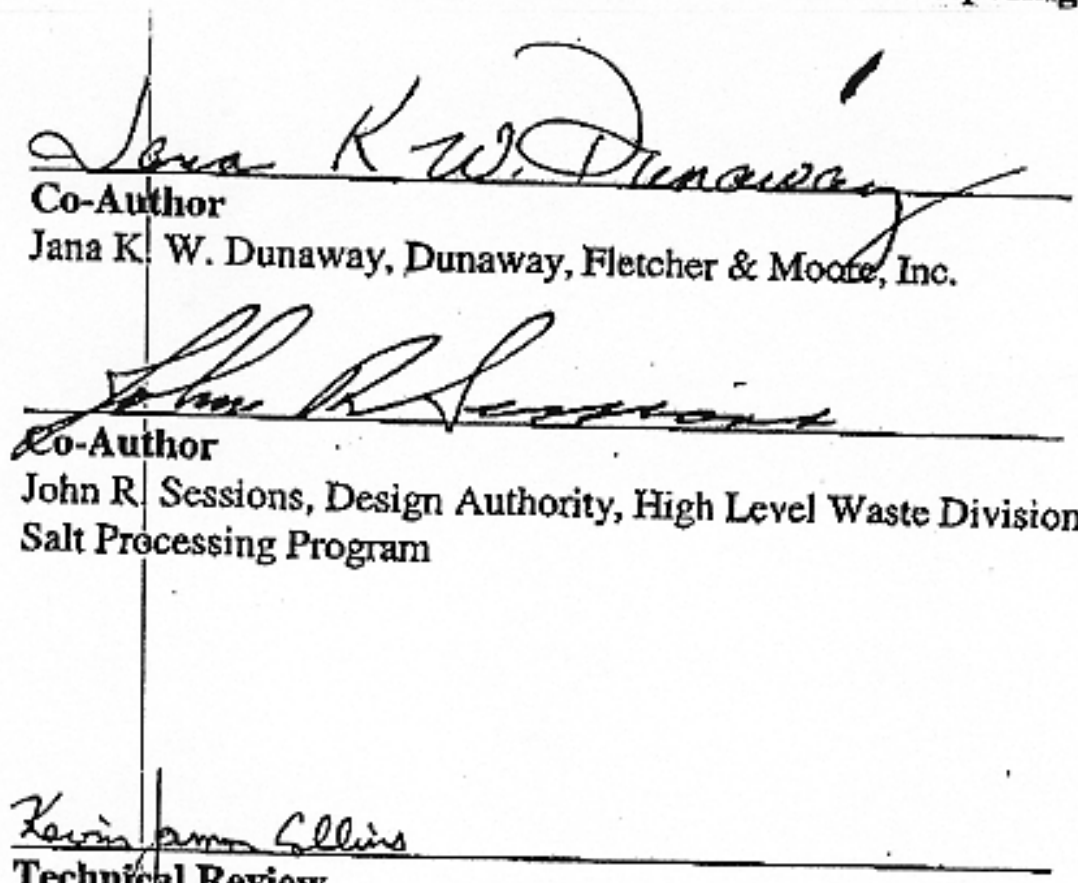

Technical Review

Kevin Y Collins, High Level Waste Division, Waste Program

Lead, CST Plant Support

Review/Concurrence

Joe T. Carter, Engineering Director, High Level Waste Division, $02114 / 02$

Salt Processing Program

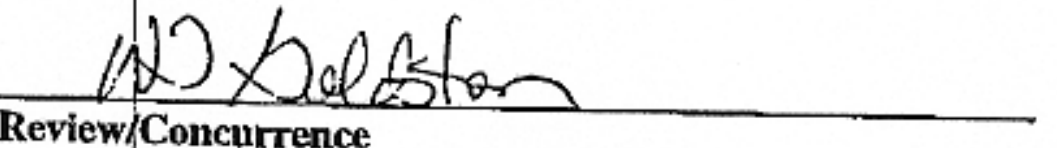

Review/Concurrence

W. T. (Sonny) Goldston, Solid Waste Division,
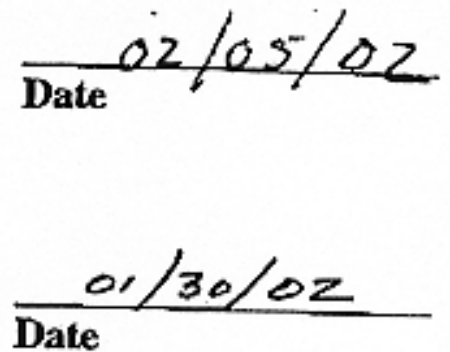

Date

Date

Solid Waste Planning and Technology

\section{$2 / 1 / 02$}

\section{Date}

$2 / 14 / 02$ Date 


\section{TABLE OF CONTENTS}

$\underline{\text { Title }}$

$\underline{\text { Page }}$

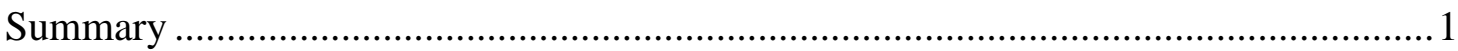

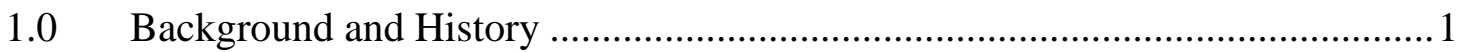

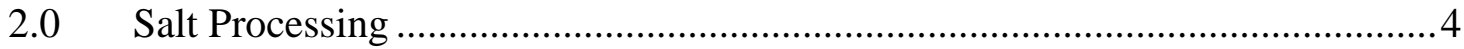

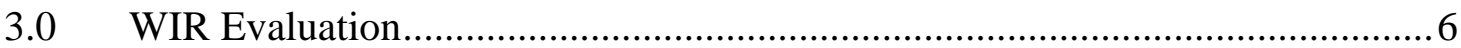

3.1 Removal of Key Radionuclides to Maximum Extent Technically and Economically Practical _.............................................. 6

3.2 Compliance with 10 CFR 61 Performance Objectives $\quad 10$

3.3 Compliance with NRC Class C Waste Limits/Stabilization _....................... 11

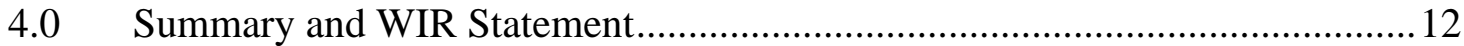

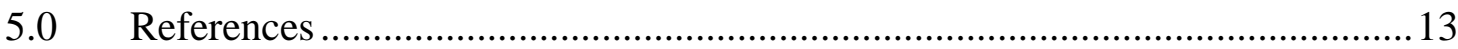




\section{LIST OF FIGURES, TABLES AND APPENDICES}

List of Figures

Page

Figure 1 Salt Waste Processing ....................................................................2

Figure 2 Processing Salt Waste Through SWPF ............................................. 4

Figure 3 Processing Salt Waste Directly to Saltstone ........................................... 4

Figure 4 Removal of Radionuclides from High Level

Waste, Saltcake to Saltstone Option .................................................... 7

Figure 5 Removal of Radionuclides from High Level

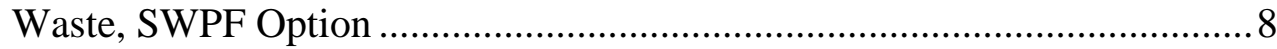

Figure 6 Relationship of Saltcake to Saltstone Documentation .............................. 10

List of Tables

Table 1 Alternative Salt Disposition Technology Selection Goals and Criteria........3

Table 2 Short List of Cesium Removal Alternatives .......................................... 3

Table 3 Candidate Tanks and Radionuclide Content ..............................................5

Table 4 Fate of Radionuclides in Salt Waste for Alternative Options .......................6

List of Appendices

Appendix A Selection of Cesium Removal Process Alternatives .........................A-1

Appendix B Projected Feed Composition ................................................. B-1

Appendix C Supporting Calculations ............................................................. 


\section{ACRONYMS AND ABBREVIATIONS}

\begin{tabular}{ll} 
Cs-137 & Cesium - 137 \\
CFR & Code of Federal Regulations \\
CSSX & Caustic Side Solvent Extraction \\
DAS & Disposal Authorization Statement \\
DOE & Department of Energy \\
DWPF & Defense Waste Processing Facility \\
EPC & Engineer, Procure \& Construct \\
HLW & High Level Waste \\
ITP & In-Tank Precipitation Facility \\
LCC & Life Cycle Cost \\
LLW & Low Level Waste \\
MST & Monosodium Titanate \\
NEPA & National Environmental Policy Act \\
Np & Neptunium \\
NRC & Nuclear Regulatory Commission \\
PA & Performance Assessment \\
Pu & Plutonium \\
Saltstone & Saltstone Production and Disposal Facility \\
Sr & Strontium \\
SRS & Savannah River Site \\
SWPF & Salt Waste Processing Facility \\
U & Uranium \\
WAC & Waste Acceptance Criteria \\
WCS & Waste Characterization System \\
WIR & Waste Incidental to Reprocessing \\
\hline &
\end{tabular}

Key Radionuclides

DOE Guidance 435.1-1 explains that key radionuclides are generally understood to be those radionuclides that have concentration limits in 10 CFR 61.55 (i.e., the long-lived radionuclides: carbon-14, nickel-59, niobium-94, technetium-99, iodine-129, plutonium-241, and curium-242; alpha emitting transuranic nuclides with half lives greater than 5 years; and the short-lived radionuclides: tritium, cobalt-60, nickel-63, strontium-90, and cesium-137), and any other radionuclides that are important to satisfying the performance objectives of 10 CFR 61, Subpart C (e.g., selenium-79, tin-126, neptunium-237). 


\section{Waste Incidental to Reprocessing Evaluation for Disposing Saltcake to Saltstone}

\section{Summary}

This Waste Incidental to Reprocessing (WIR) Evaluation is performed in accordance with Department of Energy (DOE) Order 435.1, "Radioactive Waste Management." This evaluation is performed in order to determine whether saltcake currently stored in the Tank Farms, when separated from supernate, meets WIR requirements and can therefore be managed as Low Level Waste (LLW) and disposed in the Saltstone Production and Disposal Facility (Saltstone) in ZArea. In order to be considered as meeting WIR requirements, waste must:

1. Be processed to remove key radionuclides to the maximum extent technically and economically practical,

2. Meet safety requirements comparable to performance objectives set out by the Nuclear Regulatory Commission (NRC) in Title 10, Code of Federal Regulation, Part 61 (10 CFR 61), Subpart C, and

3. Be incorporated into a solid physical form at a concentration that does not exceed concentration limits established in 10 CFR 61.55 for NRC Class C, LLW or meet alternative requirements.

This evaluation documents compliance with WIR requirements for saltcake separated from supernate. This waste, therefore, may be managed under DOE's regulatory authority in accordance with the requirements for LLW.

\subsection{Background and History}

High Level Waste (HLW) is stored in 49 tanks in the F-Area (20 tanks) and H-Area (29 tanks) Tank Farms. These tanks contain a total of approximately 37 million gallons of waste (per HLW System Plan as of January 2, 2001) with a radioactivity content of approximately 426 million Curies. The HLW consists of a sludge component ( 3 million gallons) containing approximately 226 million Curies and a salt component (34 million gallons) containing approximately 200 million Curies. Approximately 197.5 million of the 200 million Curies is Cesium - 137 (Cs137) a key radionuclide and Barium (Ba-137). The balance is in other radionuclides, including other key radionuclides. The salt component includes a solid phase known as saltcake (16.5 million gallons) and supernate (17.5 million gallons). Waste volumes and Curie content are subject to change because the supernate is evaporated to reduce its volume, and sludge is being removed for processing and vitrification (Ref. 1).

The DOE has developed a program for disposal of the wastes currently stored in the waste tanks. In this program, HLW sludge is being converted to a glass waste form by vitrification in the Defense Waste Processing Facility (DWPF). DWPF has already processed approximately 30 million Curies of the original 226 million Curies of the sludge component. The glass waste is stored onsite in stainless steel canisters pending shipment to a geologic repository for disposal. 
Original plans called for processing the salt components of the wastes (saltcake and supernate) for vitrification and disposal. This required: (1) dissolving the saltcake and combining it with the supernate to form a salt solution and (2) removing the $\mathrm{Sr}$ and alpha radionuclides ( $\mathrm{Np}, \mathrm{Pu}$, and $\mathrm{U}$ ) and separating the low-volume high-radioactivity fraction (primarily Cs-137) of the salt waste in the In-Tank Precipitation Facility (ITP). The low-volume high-radioactivity fraction would be incorporated, along with the sludge, into the glass waste form in the DWPF. The high-volume low radioactivity waste stream (inclusive of trace radionuclides including other key radionuclides not affected by processing) would be suitable for onsite disposal in Saltstone within NRC Class A limits (Figure 1, Ref. 2).

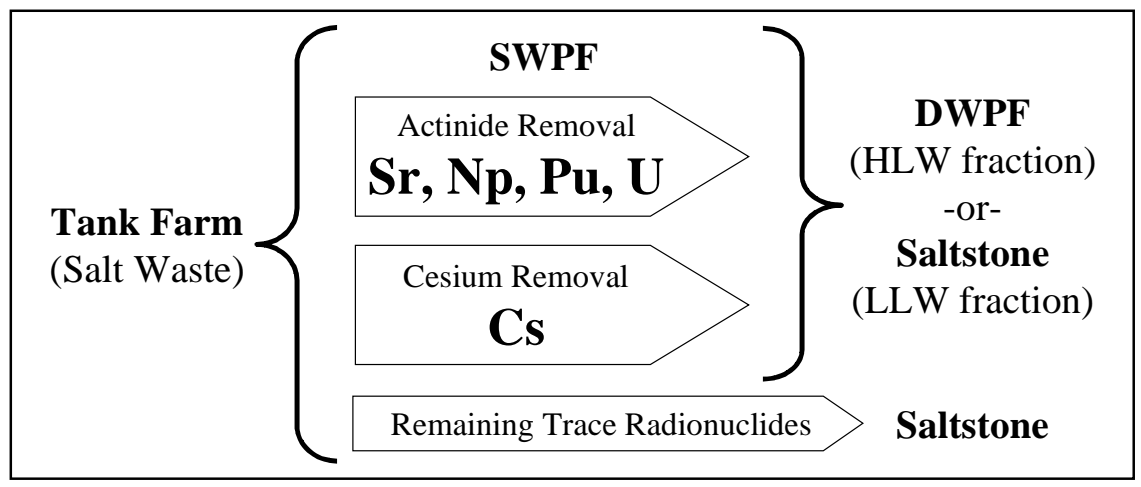

Figure 1. Salt Waste Processing

In January 1998, DOE determined that ITP, as designed, could not simultaneously meet production goals and safety requirements, because the separation of radionuclides from HLW salt solution could not be achieved without excessive tetraphenylborate decomposition and benzene generation. Without a suitable method for salt management, DOE would not be able to place the HLW in a configuration acceptable for safe disposal (Ref. 2).

To this end, alternative technologies were sought to accomplish this objective. Over 100 process alternatives were identified. In order to evaluate the alternatives, the processes were studied in an extensive research and development program, the technologies were reviewed by a number of independent groups (including two committees formed under the National Research Council) and downselection criteria were developed.

The National Research Council review included consideration of the question "Was an appropriately comprehensive set of cesium partitioning alternatives identified and are there other alternatives that should be explored?" In response, the National Research Council committee found that "...a comprehensive set of cesium partitioning alternatives was identified in the Savannah River Site's screening procedure, and it recommends that no further effort be expended in alternatives identification at this time." (Ref. 3) 
Table 1 provides the project goals (which included minimization of cost) as well as decision criteria, utilized by the DOE Technical Working Group (Ref. 4) in the technology downselect. Screening of the salt processing alternative technologies resulted in the identification of four alternative technologies for HLW salt processing in a proposed Salt Waste Processing Facility (SWPF). An overview of the selection process can be found in Appendix A.

\begin{tabular}{|l|l|}
\hline Project Goals & Decision Criteria \\
\hline Meet Schedule & - Schedule Risk \\
\hline Minimize Cost & - Project Reduction Potential \\
& - Life Cycle Costs \\
\hline Minimize Technical Risk & - Technical Maturity \\
& - Implementation Confidence \\
\hline Minimize Environmental, & - Minimizing Environmental Impacts \\
Safety and Health Risk & - Levels of Safety Control / Mitigation \\
\hline Minimize Impact to Interfaces & - Impacts of Interfaces at DWPF \\
& - Process Simplicity to Interfacing Systems \\
\hline Maximize Process Flexibility & - Maximize Process Flexibility in Throughput \\
& - Maximize Process Simplicity \\
\hline
\end{tabular}

Table 1. Alternative Salt Disposition Technology Selection Goals and Criteria

Four technologies were identified in Phase III of the downselect process, and their Life Cycle Cost (LCC) and required Z-Area Vault capacity were calculated (see Table 2). Detailed descriptions of the technologies are provided in Appendix A.

\begin{tabular}{|l|c|c|}
\hline Technology & Life Cycle Cost & Saltstone Vaults \\
\hline Caustic Side Solvent Extraction (CSSX) & $\$ 2.6 \mathrm{~B}$ & 15 vaults \\
\hline Small Tank Tetraphenylborate Precipitation & $\$ 2.1 \mathrm{~B}$ & 16 vaults \\
\hline Crystalline Silicotitanate Ion Exchange & $\$ 2.2 \mathrm{~B}$ & 13 vaults \\
\hline Direct Disposal in Grout & $\$ 1.9 \mathrm{~B}$ & 13 vaults \\
\hline
\end{tabular}

Table 2. Short List of Cesium Removal Alternatives (Ref. 5)

The National Environmental Policy Act (NEPA) decision making process was used to identify CSSX as the preferred new technology for removal of Cesium from salt waste (Ref. 5).

Investigations have indicated that a portion of the material that would otherwise be processed in the SWPF could be processed in a more cost efficient manner. Laboratory tests on simulated salt cake (Ref. 8) and hydraulic modeling of a full-scale tank (Ref. 9) indicates that it may be possible to drain the high-level fraction (supernate) away from the saltcake to allow relatively low radioactivity saltcake to be sent to the Saltstone Facility for disposal. The Record of Decision (Ref. 5) acknowledges these processes and allows multiple-parallel processes to be utilized. 


\subsection{Salt Processing}

DOE is in the process of procuring EPC contractors to design, construct and initially operate a SWPF (Figure 2) will use a Monosodium Titanate (MST) strike for actinide removal and CSSX technology for cesium removal.

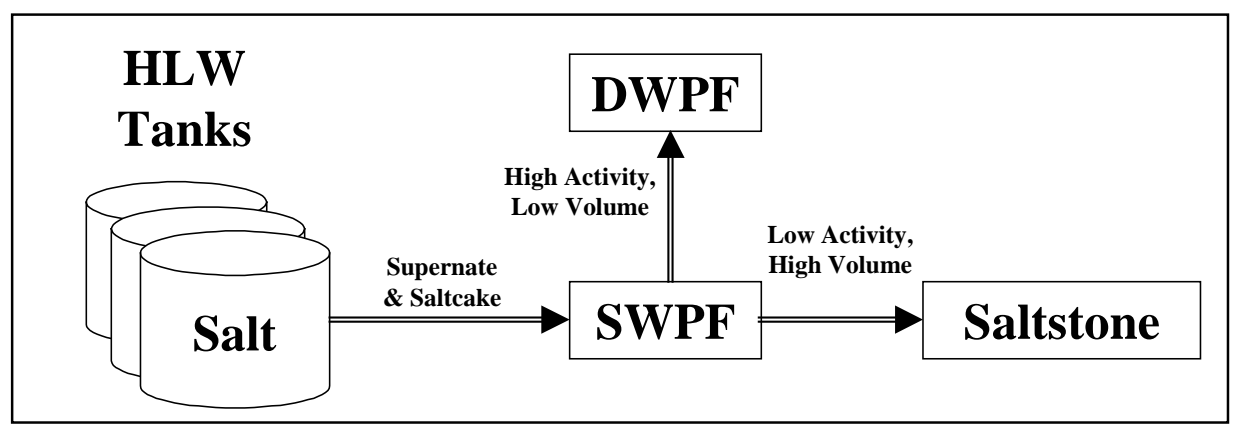

Figure 2. Processing Salt Waste Through SWPF

The initial step in the process is to remove the strontium and actinides, followed by solvent extraction, which uses a highly specific organic extractant to separate cesium from the HLW salt solution. The cesium is transferred from the aqueous salt solution into an insoluble organic phase, using centrifugal contactors to provide high surface area contact, followed by centrifugal separation of the two phases. Recovery of the cesium by back extraction from the organic phase into a secondary aqueous phase generates a concentrated cesium solution for vitrification in DWPF. Key radionuclides separated from the saltcake during processing include cesium, strontium, neptunium, plutonium and uranium. Trace radionuclides, unaffected by processing, follow the low-activity salt fraction, which is immobilized in Saltstone (Figure 1).

The alternative method of preparing salt for disposal considered in this WIR evaluation applies to low-activity saltcake that has been separated from sludge. The alternative consists of a series of

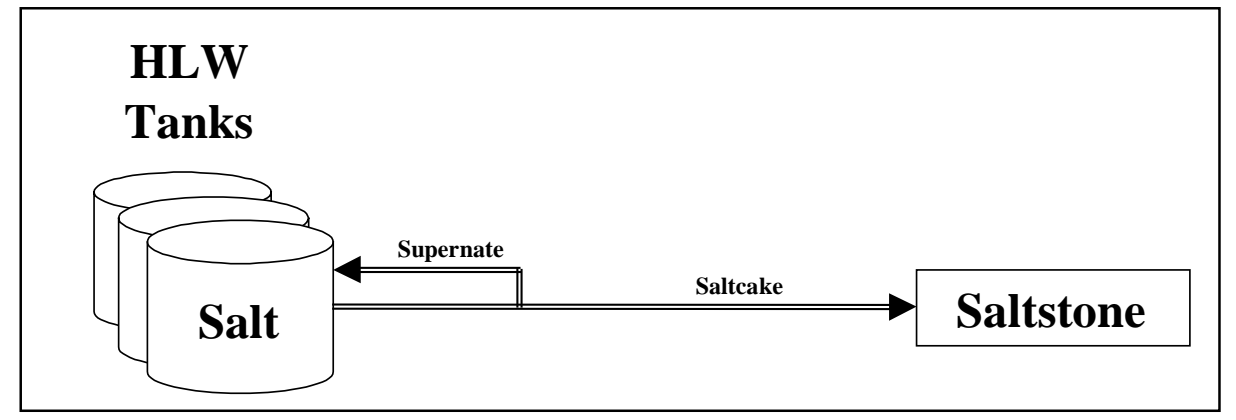

Figure 3. Processing Salt Waste Directly to Saltstone

process steps to remove key radionuclides including decanting the supernate from the saltcake, removal of interstitial supernate by pumping (Ref. 6), dissolution of the saltcake in water, verification of waste acceptance, and transfer of the solution to Saltstone for processing and disposal as saltstone (Figure 3). 
The actinide removal step proposed for the SWPF will not be incorporated into this alternative unless it is necessary to maintain Saltstone within NRC Class C limits for actinides although most actinide and $\mathrm{Sr}$ activity is separated as sludge prior to concentrating saltcake. (See Section 3.1 for economic and Section 3.2 for disposal limit descriptions.) Initially, saltcake stored in Tanks 25, 27, 28, 29, 31, 33, 34, 36, 37, 38, 41, 44, 45, 46 and 47 are candidates for this alternative (Ref. 6 and Table 3); saltcake from other HLW tanks (e.g., Tanks 1, 2, 3, 9, and 10) may also be processed in a similar manner. Although one million gallons of saltcake is used as an example in this analysis, this determination may apply to any and all saltcake processed by this method that meets the requirements discussed in Sections 3.2 and 3.3.

\begin{tabular}{|c|c|c|c|c|}
\hline Tank & $\begin{array}{c}\text { Saltcake to be } \\
\text { Processed from } \\
\text { Waste Tanks } \\
\text { (gal) }\end{array}$ & $\begin{array}{c}\text { Calculated } \\
\text { Processed } \\
\text { Saltcake } \\
\text { Solution } \\
\text { (gal)* }^{\text {Calculated Cs-137 }}\end{array}$ & $\begin{array}{c}\text { Curie Content of } \\
\text { Processed } \\
\text { Saltcake Solution } \\
\text { (Ci/gal)* }\end{array}$ & $\begin{array}{c}\text { Calculated Alpha } \\
\text { Content of } \\
\text { Processed Saltcake } \\
\text { Solution } \\
\text { (Ci/gal)* }\end{array}$ \\
\hline $\mathbf{2 5 F}$ & $1.11 \mathrm{E}+06$ & $3.31 \mathrm{E}+06$ & $3.15 \mathrm{E}-02$ & $5.09 \mathrm{E}-05$ \\
\hline $\mathbf{2 7 F}$ & $4.63 \mathrm{E}+05$ & $1.39 \mathrm{E}+06$ & $2.99 \mathrm{E}-02$ & $5.08 \mathrm{E}-05$ \\
\hline $\mathbf{2 8 F}$ & $1.03 \mathrm{E}+06$ & $3.09 \mathrm{E}+06$ & $3.28 \mathrm{E}-02$ & $5.09 \mathrm{E}-05$ \\
\hline $\mathbf{2 9 H}$ & $1.00 \mathrm{E}+06$ & $3.21 \mathrm{E}+06$ & $2.80 \mathrm{E}-02$ & $1.39 \mathrm{E}-06$ \\
\hline $\mathbf{3 1 H}$ & $1.01 \mathrm{E}+06$ & $3.29 \mathrm{E}+06$ & $7.70 \mathrm{E}-02$ & $1.38 \mathrm{E}-06$ \\
\hline $\mathbf{3 3 F}$ & $2.27 \mathrm{E}+05$ & $6.72 \mathrm{E}+05$ & $7.37 \mathrm{E}-04$ & $5.18 \mathrm{E}-05$ \\
\hline $\mathbf{3 4 F}$ & $2.12 \mathrm{E}+05$ & $6.33 \mathrm{E}+05$ & $2.56 \mathrm{E}-02$ & $5.15 \mathrm{E}-05$ \\
\hline $\mathbf{3 6 H}$ & $1.09 \mathrm{E}+06$ & $3.54 \mathrm{E}+06$ & $1.42 \mathrm{E}-01$ & $1.38 \mathrm{E}-06$ \\
\hline $\mathbf{3 7 H}$ & $9.73 \mathrm{E}+05$ & $3.15 \mathrm{E}+06$ & $1.03 \mathrm{E}-01$ & $1.38 \mathrm{E}-06$ \\
\hline $\mathbf{3 8 H}$ & $8.86 \mathrm{E}+05$ & $2.84 \mathrm{E}+06$ & $1.86 \mathrm{E}-03$ & $4.86 \mathrm{E}-05$ \\
\hline $\mathbf{4 1 H}$ & $1.23 \mathrm{E}+06$ & $3.98 \mathrm{E}+06$ & $1.72 \mathrm{E}-02$ & $4.81 \mathrm{E}-05$ \\
\hline $\mathbf{4 4 F}$ & $9.89 \mathrm{E}+05$ & $2.97 \mathrm{E}+06$ & $3.88 \mathrm{E}-02$ & $5.08 \mathrm{E}-05$ \\
\hline $\mathbf{4 5 F}$ & $1.13 \mathrm{E}+06$ & $3.38 \mathrm{E}+06$ & $3.68 \mathrm{E}-02$ & $5.08 \mathrm{E}-05$ \\
\hline $\mathbf{4 6 F}$ & $3.19 \mathrm{E}+05$ & $9.57 \mathrm{E}+05$ & $4.74 \mathrm{E}-02$ & $5.07 \mathrm{E}-05$ \\
\hline $\mathbf{4 7 F}$ & $8.68 \mathrm{E}+05$ & $2.59 \mathrm{E}+06$ & $1.97 \mathrm{E}-02$ & $5.11 \mathrm{E}-05$ \\
\hline
\end{tabular}

*Dissolution of saltcake to $6.44 \mathrm{M}$ total sodium concentration, no sludge, $10 \%$ interstitial supernate for Saltstone feed (Ref. 6).

Table 3. Candidate Tanks and Radionuclide Content

The bulk of the cesium, strontium, and neptunium, will remain in the supernate and be returned to the Tank Farms where they will eventually be processed in the SWPF. The fate of these radionuclides in salt waste for the two alternatives is summarized in Table 4 for the alternative options depicted in Figures 2 and 3 (Percentages are from Figures 4 and 5). 


\begin{tabular}{|c|c|c|c|}
\hline \multirow[b]{2}{*}{ Option } & \multicolumn{2}{|c|}{ Key Radionuclides Removed } & \multirow{2}{*}{$\begin{array}{c}\text { Remaining Trace } \\
\text { Radionuclides }\end{array}$} \\
\hline & Cs-137 & $\mathrm{Sr}, \mathrm{Np}, \mathrm{U}, \mathrm{Pu}$ & \\
\hline \multicolumn{4}{|l|}{ SWPF } \\
\hline Process/Technology & CSSX & MST strike & Not Processed \\
\hline Fate & $\begin{array}{c}\text { DWPF - 99.9975\% } \\
\text { Saltstone }-0.0025 \%\end{array}$ & $\begin{array}{c}\text { DWPF }-80.45 \% \\
\text { Saltstone }-19.55 \%\end{array}$ & $100 \%$ to Saltstone \\
\hline \multicolumn{4}{|l|}{ Saltcake to Saltstone } \\
\hline Process/Technology & $\begin{array}{l}\text { Precipitate, decant, } \\
\text { crystallize, settle, } \\
\text { decant, mine and } \\
\text { pump }\end{array}$ & $\begin{array}{l}\text { Alpha removal (to } \\
\text { DWPF) conducted } \\
\text { only as required to } \\
\text { meet applicable }\end{array}$ & Not Processed \\
\hline Fate & $\begin{array}{c}\text { DWPF - 90\% } \\
\text { Saltstone - } 10 \%\end{array}$ & limits & $100 \%$ to Saltstone \\
\hline
\end{tabular}

Table 4. Fate of Radionuclides in Salt Waste for Alternative Options

\subsection{WIR Evaluation}

\subsection{Removal of Key Radionuclides to Maximum Extent Technically and Economically} $\underline{\text { Practical }}$

The first WIR criterion is that waste be processed to the maximum extent technically and economically practical.

\section{Removal of Key Radionuclides}

Approximately 3 million gallons of HLW inventory in Tank Farms is sludge waste; the remaining 34 million gallons is salt waste. The sludge waste generally contains insoluble radioactive elements including strontium, plutonium, americium and curium in the form of metal hydroxides. Salt waste, the soluble portion of the waste, contains most of the soluble radioactive element cesium. Salt crystallizes out of salt waste and settles as saltcake at the bottom of a waste tank. The concentrated supernate is present in a free liquid layer above the saltcake; it is also present in interstitial spaces in the saltcake.

The process steps (both historic and future) to remove key radionuclides include: 1) precipitation and settling of insoluble sludge, 2) decanting and evaporation of supernate 3) crystallization of salt and settling to form saltcake, 4) decanting to separate the free supernate from the low-activity saltcake, and 5) mining into saltcake and pumping off interstitial supernate to achieve additional separation of the low-activity saltcake and interstitial supernate. Water may be added to wash out additional cesium and then pumped off to maximize cesium removal. Any step to wash additional cesium from the saltcake has an added benefit of additional removal of Sr and soluble actinides. 
Although the sludge waste contains less than $10 \%$ of the total volume of HLW, it contains approximately $53 \%$ of the Curies; a total of 226 million of the 426 million Curies of the total HLW inventory (Ref. 2). Ongoing investigations regarding various combinations of saltstone feed are evaluating the impacts of 70\%, 80\%, and 90\% supernate drainage and 0, 100, 350, and $600 \mathrm{mg}$ sludge solids/liter in feed solutions (Ref. 6). The analysis presented in this WIR evaluation assumes supernate drainage from saltcake (steps 4 and 5 above) under conditions resulting in removal of $90 \%$ of the Curies of Cs-137 from the saltcake (Ref. 6, Appendix B).

In summary, the process of separation of the sludge from salt waste removes approximately 53\% of the original Curies present in the HLW. Further processing to separate supernate from the saltcake removes an additional $90 \%$ of the Curies present in the salt waste, resulting in a total removal of approximately $95 \%$ of the radionuclides from the HLW (Figure 4).

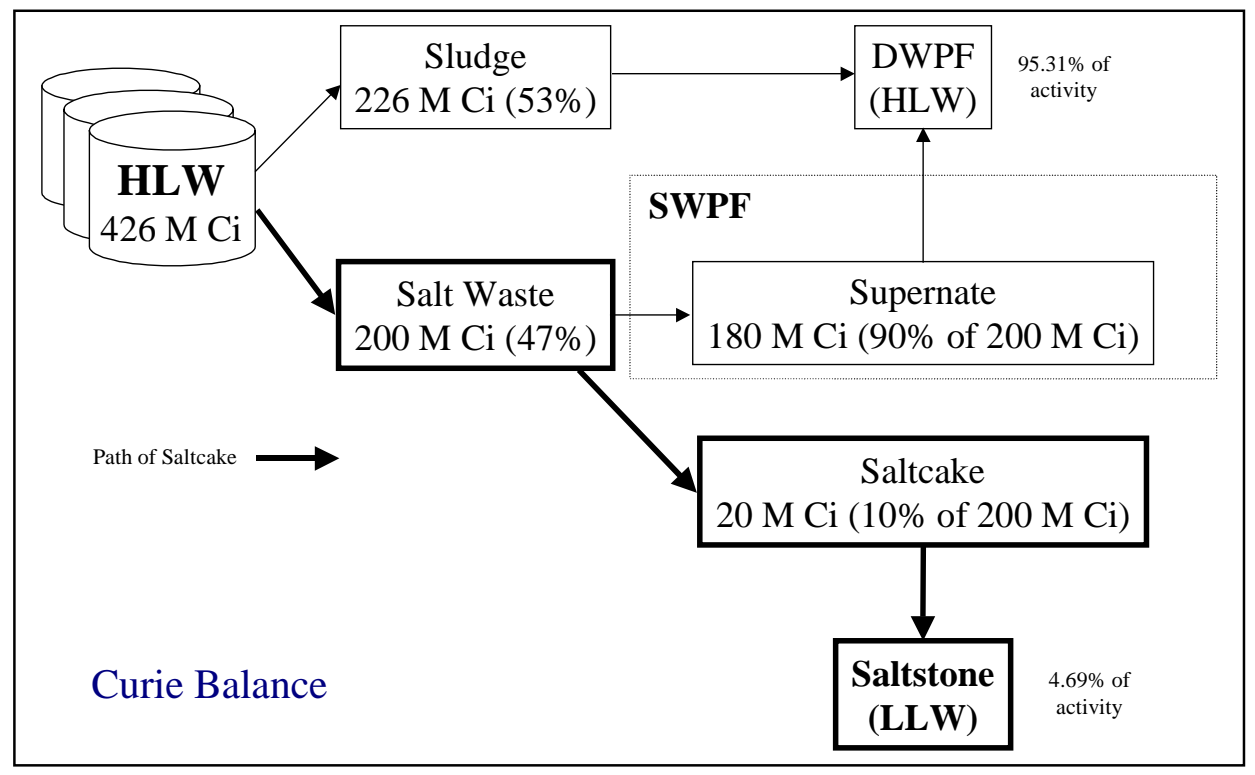

Figure 4. Removal of Radionuclides from High Level Waste, Saltcake to Saltstone Option

For the purposes of this analysis, if all saltcake went this path then the overall removal of Ci from HLW:

$$
\text { Saltcake to Saltstone Option }=\frac{226 M C i+180 M C i}{426 M C i}=95.31 \%
$$

Cs-137 accounts for approximately $18 \mathrm{M} \mathrm{Ci}$ of the remaining $20 \mathrm{M} \mathrm{Ci}$ in the Saltcake to be transferred to Saltstone. The balance is in other radionuclides, including other key radionuclides.

\section{Cost for Removal of Key Radionuclides}

The cost of processing HLW into sludge and supernate fractions and preparation of salt waste for processing in Saltstone or the SWPF are equivalent because the process is the same regardless of where the waste is destined. Therefore, this cost analysis considers only the cost of disposal of 
saltcake. The cost analysis is based upon a cost/gallon processed since the LCCs are proportional to quantity processed through the facility.

One million gallons of saltcake for alternative disposal via Saltstone was analyzed. Dissolution of the saltcake is expected to result in approximately 3.11 million gallons of decontaminated salt solution that will be transferred to Saltstone (See Appendix C).

The LCC of Saltstone is $\$ 389$ million, and its design life includes processing of 97 million gallons feed from all sources. Modifications required to Saltstone to process salt waste from the candidate tanks are projected to be no more than $\$ 5$ million. The unit processing cost for one million gallons is $\$ 17.48$ gallon of saltcake removed from the Tank Farm as illustrated in Appendix C.

\section{Cost for Additional Removal of Key Radionuclides via SWPF}

After screening hundreds of possible alternatives (Appendix A) the Supplemental Environmental Impact Statement (Ref. 2) identified four possible cesium removal technologies (Table 2) for SWPF. CSSX with actinide removal was selected as the preferred process (Ref. 5). The SWPF, using CSSX, is planned to be operational by 2010. As described in the Supplemental Environmental Impact Statement (Ref. 2), the SWPF process flowsheet includes an actinide removal step as a pretreatment to the Cs-137 removal process. Its purpose is to process the salt waste stream to remove additional key radionuclides. The technology identified utilizes a MST strike and cross flow filtration to accomplish actinide removal. The other two major candidate alternatives utilize the same actinide removal process as CSSX.

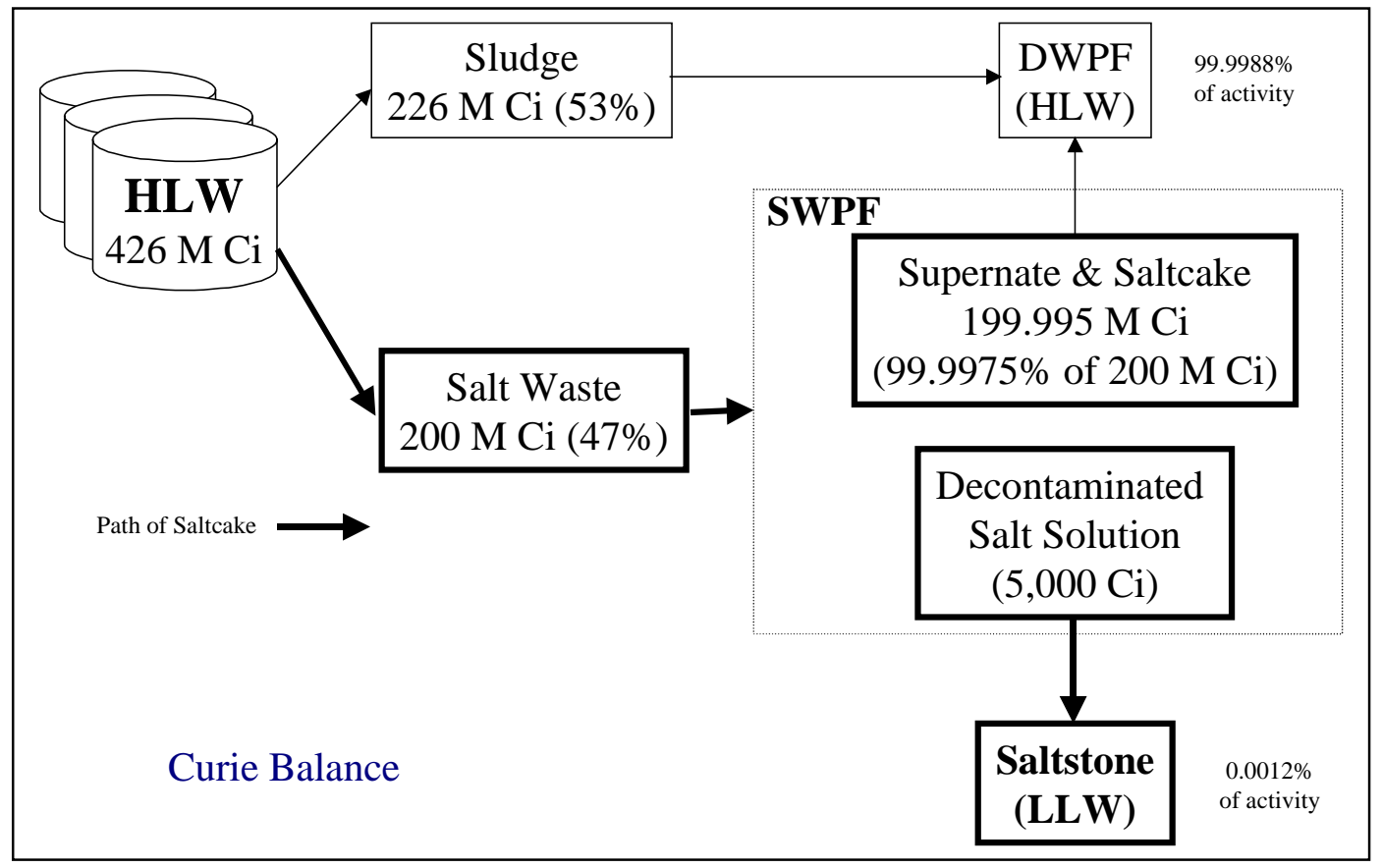

Figure 5. Removal of Radionuclides from High Level Waste, SWPF Option 
Processing of the salt waste in this facility prior to processing and disposal in Saltstone is expected to remove $99.9975 \%$ of the total Curie content (Ref. 2). Therefore, utilizing SWPF to process salt waste results in a total removal of $99.9988 \%$ of the radionuclides in HLW (Figure 5).

For the purposes of this analysis, if all saltcake went this path then the overall removal of $\mathrm{Ci}$ from HLW:

$$
\text { SWPF Option }=\frac{226 M C i+199.995 M C i}{426 M C i g a l}=99.9988 \%
$$

The same million gallons of saltcake that was analyzed for alternative disposal via Saltstone will require about 3.11 million gallons of dissolved saltcake be sent to and processed in SWPF. After processing, about 3 million gallons of decontaminated salt solution will be transferred from SWPF to Saltstone. See Appendix C.

The LCC of Saltstone is $\$ 389$ million, and its design life includes processing of 97 million gallons feed from all sources. No modifications to Saltstone would be required to process salt waste from the candidate tanks under this scenario. The unit cost for processing 1 million gallons of salt solution from the candidate tanks in Saltstone is $\$ 4.01 /$ gallon. The LCC for SWPF is $\$ 2.2$ billion and its design life includes processing of 74 million gallons. The unit cost for processing dissolved saltcake including supernate in SWPF is \$29.45/gallon. The unit cost for processing the same tank of waste through the SWPF and Saltstone is \$104.06/gal of saltcake removed from the Tank Farm, as shown in Appendix C.

\section{Comparison of Two Alternatives}

The cost to process a gallon of the candidate saltcake removed from the Tank Farm in the SWPF prior to processing through Saltstone is significantly higher than the cost/gallon for disposal of saltcake to Saltstone (\$104.06 vs. \$17.48).

Removal by the SWPF of an additional $4.7 \%$ of the HLW activity results in an incremental LCC of $\$ 86.6$ million for the million gallons of saltcake analyzed (Appendix C). The other proposed alternatives (Appendix A) were determined to be either not technically or economically practical. They use the same technology as CSSX for removal of actinides (i.e., key radionuclides other than Cs-137) and thus offer no advantage over the planned CSSX process. Therefore, it can be concluded that key radionuclide removal is completed to the extent economically and technically practical even if a lesser amount of interstitial liquid is removed, provided the Saltstone Waste Acceptance Criteria (WAC), including DOE Order 435.1 Performance Objectives and NRC Class $\mathrm{C}$ limits, are met.

The proposed alternative is insensitive to dilution rates. It will be cost effective even if more than a 9:1 dilution is necessary to control sodium content for grout manufacturing purposes in lieu of the proposed 3.11:1 dilution. 
SRS has begun an Actinide Removal Process initiative (Ref. 13). Its goal is to demonstrate on a large scale ( $>10 \%$ full scale) that a salt solution spiked with MST and then filtered will produce a low actinide/high cesium (high Curie) filtrate that is an acceptable feed stock for cesium removal via CSSX in the SWPF. If the demonstration is successful it will also allow the processing of additional low Curie salt should its actinide concentration exceed the Saltstone WAC limits. The cost reduction in the size and the processes of the SWPF will more than offset the cost of the demonstration making the Saltcake to Saltstone option even more economically attractive compared to the original SWPF option.

\subsection{Compliance with 10 CFR 61 Performance Objectives}

The second WIR criterion is that the waste meets safety requirements comparable to performance objectives in 10 CFR 61, Subpart C.

This WIR evaluation demonstrates the acceptability of saltcake to be managed as Low Level Waste. The disposal authorization for any material going to the Saltstone Facility is the DOE Disposal Authorization Statement (DAS) which requires compliance with the Saltstone WAC.

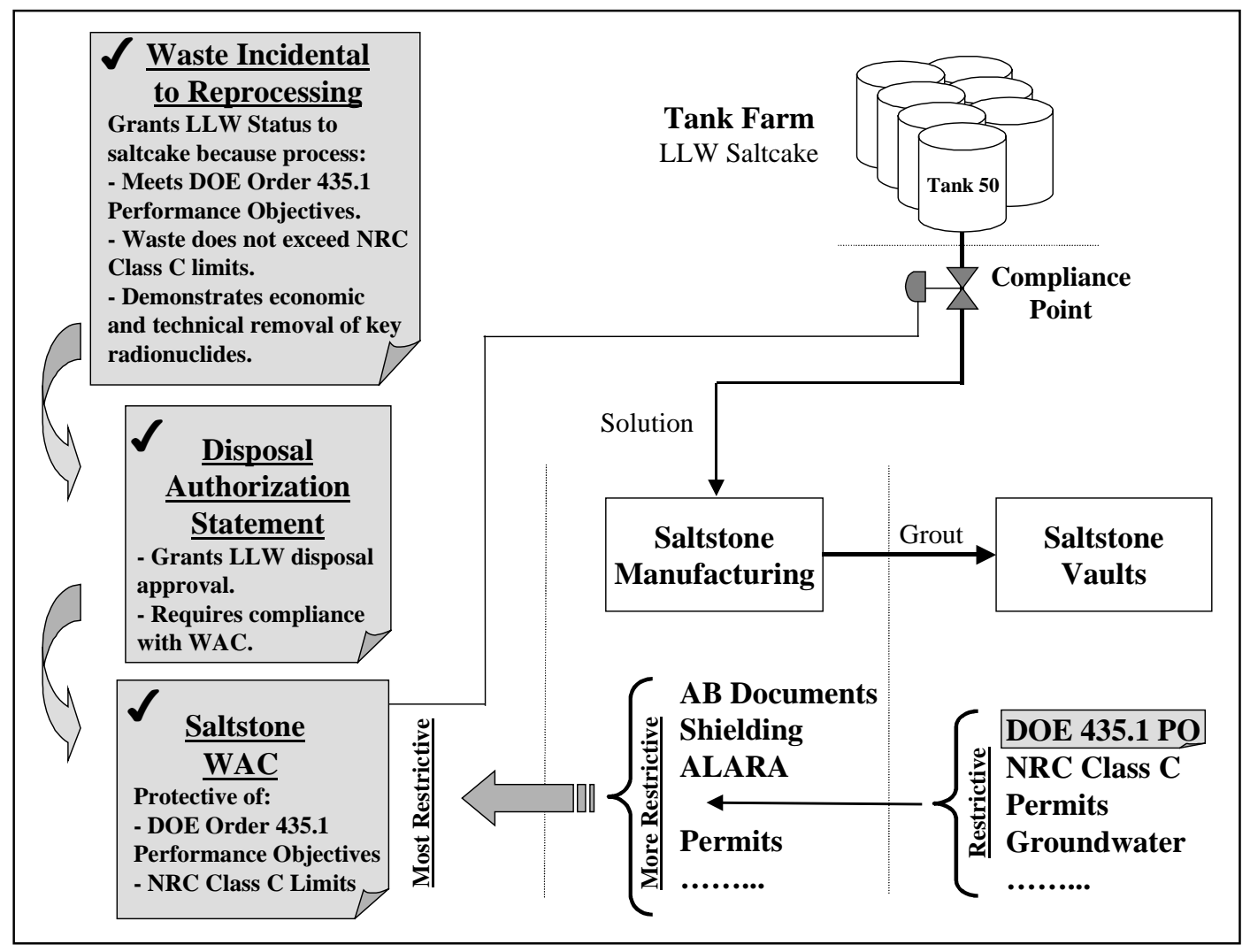

Figure 6. Relationship of Saltcake to Saltstone Documentation

The requirements for LLW disposal in DOE Order 435.1 and its predecessor Order 5820.2A, were developed from the framework laid out in 10 CFR 61. The Supplemental Environmental 
Impact Statement (Ref. 2) states that "Safety requirements contained in DOE Order M 435.1 Section IV are held to be comparable to those in 10 CFR Part 61." A comparison of the requirements of DOE Order 435.1 and 10 CFR 61 performance objectives has been performed (Ref. 7). It shows that LLW that meets Waste Acceptance Criteria (WAC) derived from a DOE Order 435.1 Performance Assessment “...will be managed to meet the safety requirements comparable to the performance objectives set out in 10 CFR 61, Subpart C, Performance Objectives."

A Performance Assessment (PA) (Ref. 11) that demonstrates that the performance objectives of DOE Order 435.1 are met for LLW disposal at Saltstone was completed in 1992. DOE reviewed and approved the Saltstone PA. In turn, the Saltstone WAC is derived from the more restrictive of the PA and NRC Class $\mathrm{C}$ limits. The WAC is also protective of the design details, criticality, and ALARA that may be even more restrictive than the PA or NRC Class C limits (Figure 6).

Prior to first disposal of waste at a facility a DAS must be issued. A DAS specifies the limits and conditions on design, construction, operations and closure of a waste facility. As such, the Saltstone DAS specifies that Saltstone shall have a WAC that demonstrates that the performance objectives of DOE Order 435.1 are met. DOE has issued and approved a DAS for Saltstone (Ref. 12). Therefore, waste transfers must meet the conditions of the WAC at the compliance point.

Thus, prior to any transfer of saltcake solution from the Tank Farm to Saltstone, this WIR evaluation, the appropriate Saltstone DAS and WAC shall be approved and in place. The WAC shall be protective of the most restrictive requirements, including DOE Order 435.1 Performance Objectives (PO) and NRC Class C limits, and be protective of the public, workers, and environment.

The Curie content of the salt solution to be transferred to Saltstone will be sampled at Tank 50 (compliance point) and verified against the Saltstone WAC prior to transfer to Saltstone. The waste will not be transferred to Saltstone for disposal if it is not within the limits established in the WAC. Instead the waste will be returned to the Tank Farm.

Appropriate administrative controls will be in place to ensure that saltcake to be transferred for disposal will meet the Saltstone WAC limits, thereby ensuring that Saltstone shall meet 10 CFR 61 and DOE Order 435.1 Performance Objectives, and shall be within NRC Class C Limits.

\subsection{Compliance with NRC Class C Waste Limits/Stabilization}

The third WIR criterion is that the waste be incorporated into a solid physical form at a concentration that does not exceed concentration limits for NRC Class C LLW or meets alternative requirements.

The saltstone waste form, the final product of salt stabilization, is a solid physical form consisting of waste mixed with cement, flyash and slag. As discussed above, the WAC for Salt to Saltstone will be protective of DOE Order 435.1 PO and NRC Class C Limits as well as be 
protective of design details, criticality, and ALARA concerns.

Since the saltstone waste form identified in this document is a solid physical form and shall meet NRC Class C limits, it also meets this WIR requirement of DOE Order 435.1.

\subsection{Summary and WIR Statement}

A WIR evaluation was performed on saltcake intended for ultimate disposal in Saltstone. The evaluation is summarized as follows:

- As much as $95 \%$ of Cs-137 can be removed from F- and H-Tank Farm HLW processed in the proposed alternative. The incremental cost to remove the remaining Curies from one million gallons is $\$ 86.6$ million. For the proposed alternative, key radionuclides will be removed to the extent economically and technically practical.

- The saltstone waste form identified in this document shall be assured to meet the Saltstone WAC limits, thus Saltstone shall meet 10CFR61 and DOE Order 435.1 Performance Objectives by establishment of operational limits within applicable Performance Objective and NRC criteria.

- The saltstone waste form identified in this document is a solid physical form and shall meet NRC Class C limits by establishment of operational limits within NRC Class C Limits. NOTE: The first waste planned to be processed using this WIR evaluation is expected to be well below the Class $\mathrm{C}$ limits.

In summary, saltcake in the SRS Tank Farm meets WIR evaluation criteria and can be managed in Saltstone as LLW. 


\subsection{References}

1. Westinghouse Savannah River Company (WSRC), "SRS High Level Waste System Plan, HLW-2000-00040”, Rev. 12, Aiken, South Carolina, March 2001.

2. Department of Energy, "Savannah River Site Salt Processing Alternatives Supplemental Environmental Impact Statement," DOE/EIS-0082-S2, March 2001.

3. National Research Council, "Alternatives for High-Level Waste Salt Processing at the Savannah River Site,” Washington D.C., 2000.

4. Department of Energy, "Final Technical Working Group Report on the Salt Processing Project Facility," June 2001.

5. Record of Decision: Savannah River Site Salt Processing Alternatives, Federal Register: Volume 66, Number 201, Page 52752-52756, October 17, 2001.

6. J. A. Pike, et. al., "Feed Basis for Processing Relatively Low Radioactivity Waste Tanks," WSRC-TR-2001-00559, Rev. 0, December 2001.

7. E. L. Wilhite, "Comparison of LLW Disposal Performance Objectives 10 CFR 61 and DOE 435.1,” WSRC-RP-2001-00341, Rev. 0, March 2001.

8. B. J. Wiersma, “An Investigation of Density Driven Salt Dissolution Techniques”, WSRCTR-96-0160, August 1996.

9. J. N. Brooke, J. F. Peters, and K. Staheli, "Hydrological Methods Can Separate Cesium From Nuclear Waste Salt Cake”, WSRC-TR-99-00358, October 1999.

10. J. R. Hester, "High Level Waste Characterization System (WCS)", WSRC-TR-96-0264, Rev. 0, December 1996.

11. Westinghouse Savannah River Company (WSRC), "Radiological Performance Assessment for Z-Area Saltstone Disposal Facility,” WSRC-RP-92-1360, Aiken, South Carolina, 1992.

12. Department of Energy, "Disposal Authorization Statement (DAS) for the SRS E-Area Vaults and Saltstone Disposal Facilities," September 1999.

13. Westinghouse Savannah River Company (WSRC), "Actinide Removal Process Alternative Study and Selection,” G-ADS-G-00007, Rev. 0, Aiken, South Carolina, January 2002. 


\section{APPENDIX A}

\section{Selection of Cesium Removal Process Alternatives}

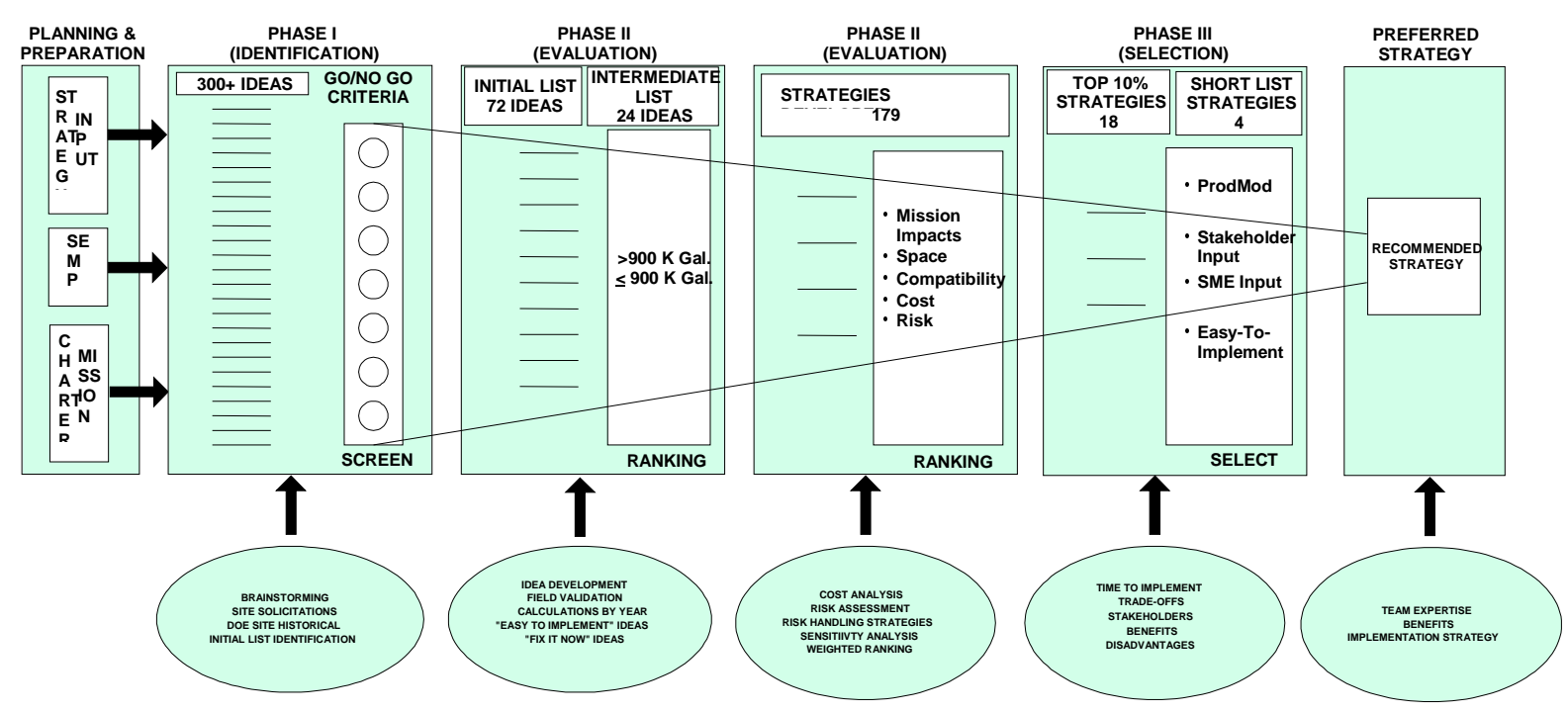

\section{Initial Selection of Cesium Removal Process Alternatives (Phase I - 'Long List') as listed by the National Research Council (Ref. 3)}

1. Crystallization - separation of cesium from non-radioactive salts by fractional crystallization [6 alternatives: 6 accepted and combined into 3, 0 rejected].

2. Electrochemical - processes which achieve separation/destruction of different ionic components in the system [5 alternatives: 5 accepted and combined into 2, 0 rejected].

3. Elutable Ion Exchange - separation of cesium from HLW salt by regenerable ion exchange [17 alternatives: 13 accepted and combined into 3, plus 1 accepted and combined under Non-Elutable Ion Exchange, 4 rejected].

4. Non-Elutable Ion Exchange - separation of cesium from HLW salt by non-regenerable ion exchange [3 alternatives: 25 accepted and combined into 7, plus 2 accepted and combined under Elutable Ion Exchange, 6 rejected].

5. Geological - alternatives more dependent on geology than processing [3 alternatives: 0 accepted, 3 rejected].

6. Inorganic Precipitation - separation of cesium by addition of an inorganic precipitant [4 alternatives: 0 accepted, 4 rejected]. 
7. Organic Precipitation/Modify In-Tank Precipitation (ITP) - separation of cesium by addition of an organic precipitant with extensive use of the existing ITP facility [29 alternatives: 21 accepted and combined into 4, plus 4 accepted and combined under Organic Precipitation/New Process, 8 rejected].

8. Organic Precipitation/New Process - separation of cesium using a facility substantially different from the existing ITP facility [17 alternatives: 10 accepted and combined into 1 , plus 2 accepted and combined under Elutable Ion Exchange, 7 rejected].

9. Solvent Extraction - use of a solvent for separating cesium based on either an alkaline or acidic feed stream [ 6 alternatives: 5 accepted and combined into 2, 1 rejected].

10. Vitrification - disposition of the salt by vitrifying it either in Defense Waste Processing Facility (DWPF) or using new equipment or facilities [8 alternatives: 2 accepted, 6 rejected].

11. Miscellaneous - approaches not covered by the other categories [18 alternatives, including 1 new hybrid: 5 accepted including 1 hybrid, 13 rejected].

\section{Short List of Cesium Removal Alternatives (Phase III) as listed in the Environmental Impact Statement (Ref. 2)}

1. Caustic Side Solvent Extraction

A technology alternative (\$2.6B LCC) for processing the HLW salt solution to remove radioactive cesium by transfer to an immiscible organic stream, from which it is recovered into a secondary aqueous stream for vitrification at the DWPF. Before cesium is removed from the salt solution, radioactive strontium and actinides are removed by sorption onto MST and vitrified in DWPF. The remaining low-activity waste stream is immobilized in grout and disposed of as saltstone in onsite vaults (required Z-Area capacity for implementation: 15 vaults).

\section{Small Tank Tetraphenylborate Precipitation}

A technology alternative (\$2.1B LCC) for processing HLW salt solution to remove radioactive cesium by precipitation as an insoluble tetraphenylborate salt concurrently with removal of radioactive strontium and actinides by sorption onto MST. The process would be carried out by continuous reaction in small process vessels to limit benzene formation caused by tetraphenylborate decomposition. These solids are vitrified in the DWPF and the remaining low-activity salt solution is immobilized in grout and disposed of as saltstone in onsite vaults (required Z-Area capacity for implementation: 16 vaults). 


\section{Crystalline Silicotitanate Ion Exchange}

A technology alternative $(\$ 2.2 \mathrm{~B}$ LCC) for processing HLW salt solution to remove radioactive cesium by absorption onto a siliconate ion exchange resin that would be incorporated into a glass waste form by vitrification in the DWPF. Radioactive strontium and actinides are removed by sorption onto MST prior to ion exchange and vitrified in DWPF. The remaining low-activity salt solution is immobilized in grout and disposed as saltstone in onsite vaults (required Z-Area capacity for implementation: 13 vaults).

\section{Direct Disposal in Grout}

A technology alternative (\$1.9B LCC) for processing the HLW salt solution without removal of radioactive cesium by immobilization in grout for onsite disposal as saltstone (required Z-Area capacity for implementation: 13 vaults). Radioactive strontium and actinides are removed prior to disposal and vitrified in DWPF. 


\section{APPENDIX B}

\section{Projected Feed Composition}

Salt cake in HLW tanks consists of crystallized salts with interstitial space and entrained insoluble solids commonly referred to as sludge solids. The feed material for processing relatively low radioactivity waste tanks consists of the salt cake dissolved to an assumed $6.44 \mathrm{M}$ total sodium concentration. The total interstitial void is assumed to be $22 \%$ (Ref. 10) and is assumed to consist of gas and supernate. Prior to dissolving the salt cake, the interstitial space is assumed to be drained such that little liquid supernate remains. Such drainage has been shown to be possible in laboratory tests on simulated salt cake (Ref. 8). Hydraulic modeling of a full-scale tank indicates the same may be possible at full-scale (Ref. 9).

Chemical and radionuclide concentrations for salt cake and supernate in each waste tank with salt cake are extracted from the "High Level Waste Characterization System" (WCS), (Ref. 10). WCS indicates radionuclides are assumed to be in the interstitial supernate and any entrained sludge solids and not in the salt cake solids. Projected salt solution feed composition listed below is extracted from Ref. 6 and utilizes a feed basis after dissolution to $6.44 \mathrm{M}$ total sodium concentration, no sludge and $10 \%$ interstitial supernate. All feed to be transferred to Saltstone will be sampled and verified against the WAC prior to transfer. Only feed that meets the WAC will be transferred.

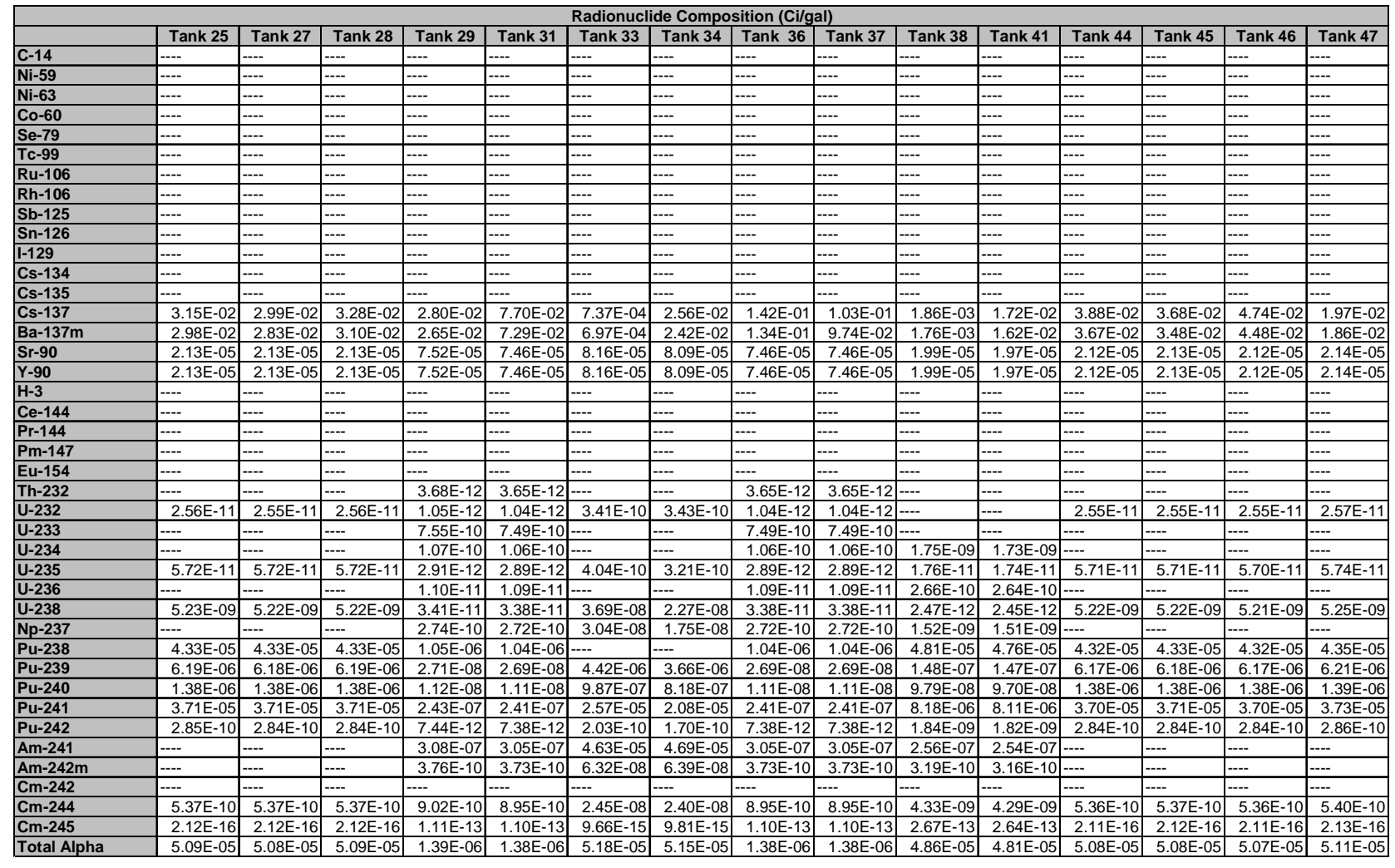




\section{APPENDIX C}

\section{Supporting Calculations}

(Based on 1M gallon Saltcake Removed from Tank Farm)

\section{$\underline{\text { Assumptions }}$}

- Average Dissolution of saltcake to $6.44 \mathrm{M}$ total sodium concentration, no sludge, $10 \%$ interstitial supernate $($ Table 2$)=3.11$ times

- Life Cycle Cost Saltstone (Ref. 1) = \$389,410,000

- Life Cycle Gallons Processed Saltstone (Ref. 2) =97,000,000gal

- Life Cycle Cost SWPF (Ref. 1) = \$2,179,355,000

- Life Cycle Gallons Processed SWPF (Ref. 2) = 74,000,000gal

\section{Processing Cost, Disposal via Saltcake to Saltstone}

Life Cycle Processing Cost, gallon basis $=\frac{\$ 389,410,000}{97,000,000 \mathrm{gal}}+\frac{\$ 5,000,000}{3,110,000 \mathrm{gal}}=\$ 5.62 /$ gallon

Life Cycle Cost, Disposal to Saltstone Option $=3,110,000 \mathrm{gal} * \$ 5.62 / \mathrm{gal}=\$ 17,478,200$

Unit Processing Cost, gallons saltcake removed basis $=\$ 17.49 /$ gallon

\section{Processing Cost, Disposal via SWPF}

SWPF Life Cycle Processing Cost, gallon basis $=\frac{\$ 2,179,355,000}{74,000,000 \text { gal }}=\$ 29.45 /$ gallon

Saltstone Life Cycle Processing Cost, gallon basis $=\frac{\$ 389,410,000}{97,000,000 \text { gal }}=\$ 4.01 /$ gallon

Life Cycle Cost, SWPF Option $=3,110,000 \mathrm{gal} * \$ 29.45 / \mathrm{gal}+3,110,000 \mathrm{gal} * \$ 4.01 / \mathrm{gal}=$ $\$ 104,060,600$

Unit Processing Cost, gallons saltcake removed basis $=\frac{\$ 104,060,600}{1,000,000 \text { gal }}=\$ 104.06 /$ gallon

\section{Cost Comparison of 2 Options}

Difference in overall removal $=99.9988 \%-95.31 \%=4.6892 \%$

Incremental cost $=\$ 104,060,600-\$ 17,478,200=\$ 86,582,400$ 